\title{
STRENGTHENING THE BASIC KNOWLEDGE OF STATISTICS AND PROBABILITY FOR TEACHERS OF BASIC EDUCATION
}

\author{
Augusta Osorio and Elizabeth Advincula \\ Pontificia Universidad Católica del Perú, Perú \\ arosorio@pucp.edu.pe
}

Our research is applied and seeks to develop workshops that will target and strengthen the basic content of Statistics and Probability of primary teachers. The workshops will follow closely the content considered within the Progress Map of Statistics and Probability. This content is part of the new National Learning Standards which was prepared by Ministry of Education. Our work will involve the design, application and continuous assessment of experiential workshops. This process will ensure the constant revision and improvement of any problems that may arise during their implementation. In accordance with the Progress Map of Statistics and Probability, the workshops will develop the following three aspects: gathering and data processing, interpretation and evaluation of data, and the analysis of uncertainty.

\section{PURPOSE}

Our research seeks to develop workshops that will target and strengthen the basic content of Statistics and Probability of elementary teachers in order to make an effective work in the classroom. The workshops will follow closely the content considered within the Progress Map of Statistics and Probability. This content is part of the new National Learning Standards which was prepared by the Peruvian Institute of Evaluation, Accreditation and Certification of Quality Basic Education (IPEBA) in conjunction with the Ministry of Education.

The Progress Map of Statistics and Probability describes the progressive development of two skills: the process and interpretation of diversity of data in order to transform them into information; and the analysis of situations of uncertainty in order to formulate predictions that allow taking appropriate decisions. This description is made based on three aspects: gathering and data processing, interpretation and evaluation of data, and the analysis of uncertainty.

The first aspect relates to the capacity to work with data. It means to compile, sort, organize, represent and determine their descriptive measures according to a purpose and in order to provide input for the interpretation of this data. The second aspect indicates the capacity to convert the data processed into information by reading, interpretation, inference and valuation of the reliability and representativeness of the data in order to make decisions. And the last point is associated with the capacity to identify, describe, model a random situation, determine its components (sample-space, context and constraints) and estimate the probability of occurrence of the events related to it, in order to predict and make decisions.

Our work will include the design, application and strengthening of workshops developed to work the topics involved in the three aspects seen in the Progress Map of Statistics and Probability for the elementary grades.

The workshops will be designed based on the information collected from pilot workshops with about 150 elementary teachers from different regions of the country conducted during 2014, and from the achievement results obtained from evaluations given to 380 elementary students, measured on basis of the contents of the Progress Map of Statistics and Probability.

\section{BACKGROUND}

In our country, the addition of Statistics and Probability topics at the elementary grades was performed since the second grade, and the proposal on the Progress Map suggests that it should be performed since the kindergarten ( 5 years old). However, we know that the inclusion of Statistics and Probability topics in the national curriculum does not ensure their teaching, i.e. this may only remain on paper. This problematic has already been established by some researchers as Jiménez and Jiménez (2005) or Grima (2010), who point out that in many countries Statistics and probability are taught at the end of mathematic courses and in many cases these topics are hardly studied or not seen at all.

In: M.A. Sorto (Ed.), Advances in statistics education: developments, experiences and assessments. Proceedings of the Satellite conference of the International Association for Statistical Education (IASE), July 2015, Rio de Janeiro, Brazil. 
A direct consequence of this problem is that the level of knowledge of Statistics and Probability of students who graduate from high school is very poor. For the last 8 years we have systematically observed the lack of our students' basic knowledge during their first course of Statistics at the university level, which has both worried and motivated us to investigate more about the basic knowledge of Statistics that students acquire during their school years.

Our research during 2013 focused on this concern, Advincula and Osorio (2015). We considered the measurement at two different points during the course of elementary and secondary education: students completing the 4th grade and students finishing the second year of high school. The results allowed us to conclude that there are some aspects of the teaching of Statistics and Probability that are not taught or achieved in the expected time frame.

This has led us to consider that the problem is not only in the limited time given to the teaching of Statistics and Probability or the fact that these are topics taught at the end of the school year, but also in many cases the problem is in the educators' lack of interest in this subject matter or lack of mastery in how to teach these topics. Lots of researchers have investigated these points, like Batanero (2009), who shows the analysis of different investigations concerning educators receiving training in Statistics, or Estrada (2010), who applies different methods in order to relate the attitude towards the teaching of Statistics with the mastery of basic concepts by educators both in activity and in training.

Another important variable to add is our teaching experience. We have taught Statistics and Probability to teachers enrolled in the Virtual Certified Program for the Teaching of Mathematics in the elementary grades, which is taught in the Faculty of Education at the PUCP. The course was given on four different occasions to an average of 60 attendees at a time. Some of the participants presented serious deficiencies and a lack of knowledge of Statistics and Probability. In many cases these deficiencies were the result of inadequate preparation in these subjects and not for lack of interest.

These deficiencies also became apparent during discussions with elementary teachers in the pilot workshops, where they expressed their concerns regarding the teaching of Statistics and especially the teaching of Probability.

Based on the information gained during the process of this investigation, we can say that an important step in improving students' learning of Statistics and Probability is to support and enhance the mastery of basic Statistics and Probability skills of teachers. The preparation and implementation of workshops to strengthen the statistical thinking of elementary teachers is one of the best ways to start a process that leads to long-term improvement in the mastery of Statistics and Probability in students during their basic education.

\section{DESIGN}

The process of design began with the alignment of the workshops of 2015. In early 2014, we began a series of pilot workshops in collaboration with the Institute of Research in Mathematical Education IREM-PUCP. These workshops had the following goals: measure the ability of educators to solve problems of Statistics and Probability based on the context of the Progress Map of Statistics and Probability; discuss and explain to educators the importance of these topics in the learning development of students in the elementary grades; determine and establish with educators what basic knowledge is needed to teach effectively Statistics and Probability in the elementary grades; revise and study basic Statistics and Probability concepts considered within the contents of the Progress Map; and review student tasks proposed by teachers for classroom work.

We are currently in the process of evaluating the information gathered from tests given to teachers in order to identify types of errors and, thus, establish strategies to avoid them. What we can anticipate is that there are a percentage of elementary teachers who have similar errors to those found in students, Figure 1.

We have also observed that the degree of knowledge of teachers regarding some issues related to Probability is very poor. Some teachers had serious difficulties in distinguishing an "event" from a "sample-space" and an "event" from a "random situation".

The information collected during the pilot workshops helped us to establish the basic format for our workshops: revision of basic concepts, revision of learning indicators included in the new learning standards, revision of student errors, and creation of problems. 


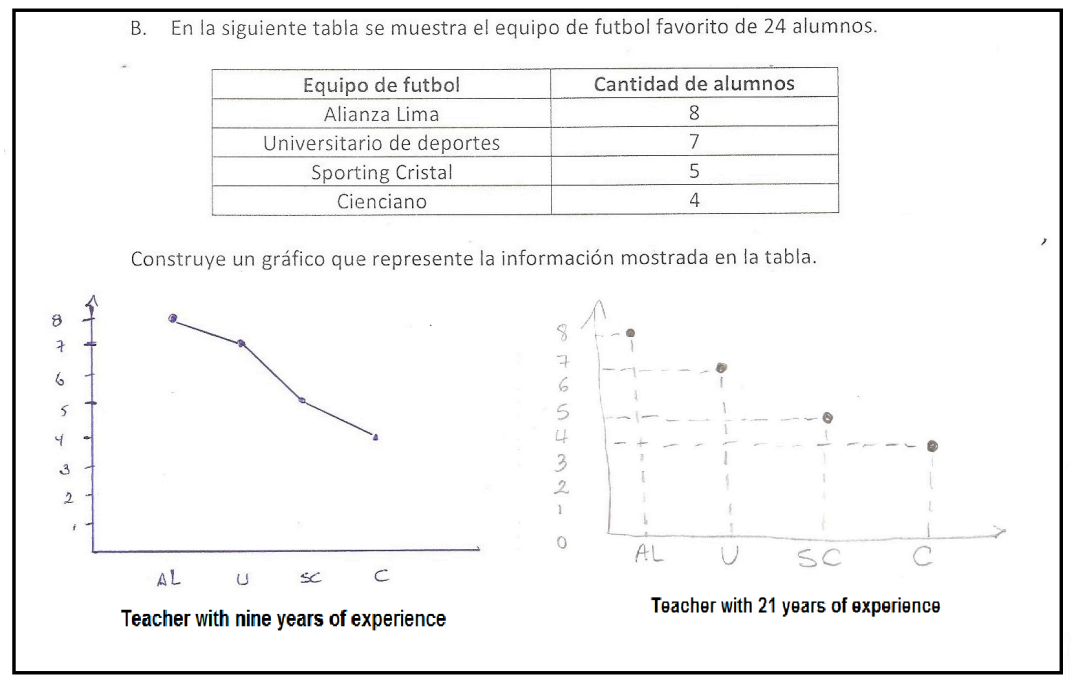

Figure 1: Graph a qualitative variable

In order to establish the emphasis in the presentation of the workshop topics, we have decided that the theory of statistical thinking as defined by Wild and Pfannkuch (1999) is the most pertinent for work related to the gathering, processing, interpretation and valuation of data. The first dimension of this theory, the planning of the Research Cycle (PPDAC), refers to what the researcher does and thinks during the realization of the investigation. This is fundamental for an adequate use of the topics in the first two aspects of the Progress Map,

During the pilot workshops, we learned that elementary teachers have some command of the issues related to the organization of data using single and double tables as well as of the presentation of data using different graphic organizers, but they have difficulties relating these topics to concepts such as statistical variable, population, sample and questionnaire. In short, they do not recognize the importance of the phases of a problem and how to develop a plan to resolve it, nor how to adapt such an approach to the level of their students.

We also noticed that they saw no need to complete a problem of statistics based on an initial question within a proposed context. It was enough for them if students responded mechanically to diverse questions related to tables or graphic organizers. That is, they did not see the importance of students using the process as a means to obtain information and reach a possible conclusion on a proposed problem.

The main focus of the workshops is to strengthen the PPDAC cycle and find ways to incorporate this teaching into the elementary levels.

One of the substantial modifications introduced in the Progress Map was the inclusion of contents related to probabilities since 5 years old, and working probabilities based on the classical approach in the $\mathrm{V}$ cycle of the elementary grades. This will involve a further development of the elementary teachers in these topics. As we saw in the pilot workshops, only $10 \%$ of teachers could properly define the concept of probability and less than $30 \%$ of them could solve a simple problem of probabilities based on the classical approach, Figure 2.

For the Workshops aimed at teaching Probability, our main concern will be the consolidation of basic concepts. What we will use as didactic framework is the research of Osorio (2012). This paper uses the random situation as the basic concept for understanding of probability and allows articulating all the concepts related to the probability around the classification of random situations. It is expected that the review of the concepts based on this framework allows to the teachers a better understanding of what to expect of students in each grade of elementary school.

The duration of each workshop will be twenty hours divided in three parts. In the workshop of Statistics: five hours will be dedicated to the review of concepts and students' mistakes; other five hours to the work with learning indicators; and the remaining ten hours to the building of problems by teachers. In the case of the workshop of Probability: ten hours will be dedicated to the 
review of concepts; five hours to work with the indicators; and the remaining five hours to the construction of problems.

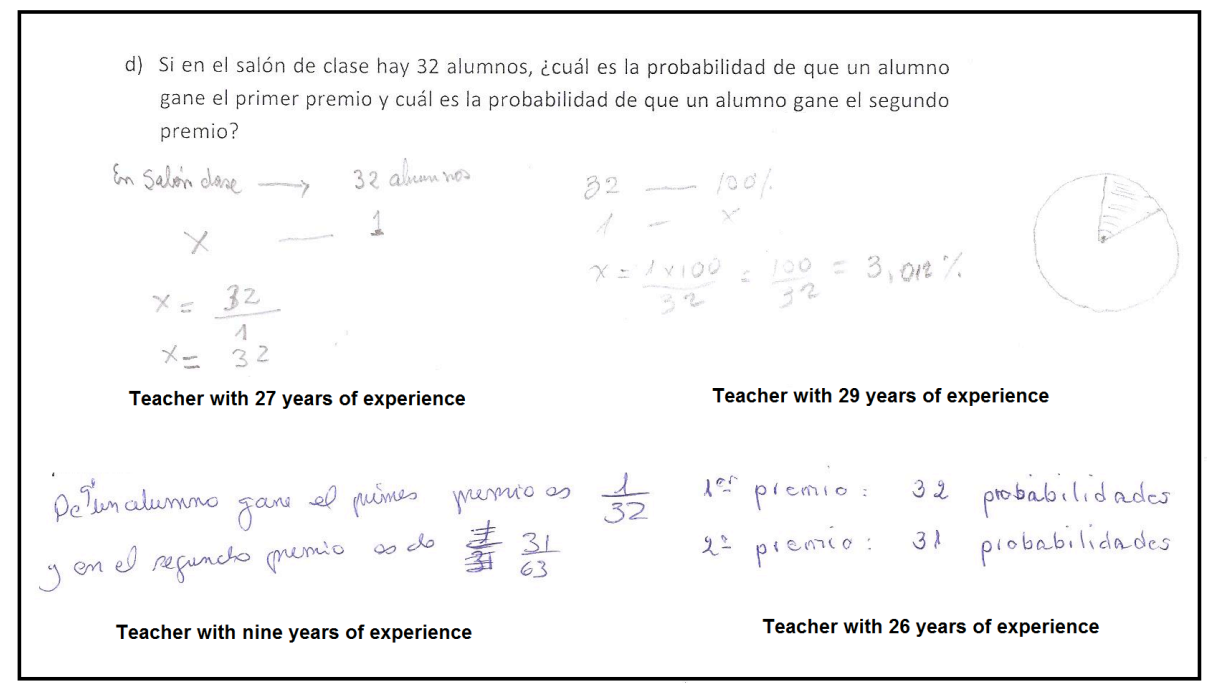

Figure 2: Classical approaches to probability

The strategies to be used are as follows: collaborative activities meant to serve as a review of the topics in each session; plenaries to consolidate concepts; reviews of the problems developed by the educators for the students and the development of ideal solutions; reviews of incorrect answers given by students during the investigation in 2013 and discussions of possible causes; group activities to collectively create problems for a specific subject and grade level; plenaries to discuss any proposed problems and possible solutions or improvements.

\section{RESULTS}

What is considered as the main product of this research is the design of the two workshops, and the experience gained during their application.

Another product will be the activities created by teachers during the workshops. These activities are to be revised and improved by the teachers with our support. In order to analyze their effectiveness, teachers will implement them in their classrooms.

\section{IMPLICATIONS FOR THEORY AND PRACTICE}

The expected impacts are as follows: the dissemination of teacher experiences in their own schools as well as in the areas of teacher training in the various Faculties of Education in the country and the development of reference materials for the area of Statistics and Probability aimed at teachers of Regular Basic Education.

\section{RELEVANCE}

The product of this research will be relevant for all educational institutions of our country interested in training their teachers because it will allow them to have a product that promotes more competent teachers and better teaching of content in Statistics and Probability. This, in turn, will enable students to begin their secondary education with knowledge of basic statistical concepts.

\section{REFERENCES}

Advincula, E., \& Osorio, A. (2015). Midiendo los logros de estudiantes de la Educación Básica Regular en Estadística y Probabilidad. J. M. Contreras, C. Batanero, J. D. Godino, G.R. Cañadas, P. Arteaga, E. Molina, M.M. Gea y M.M.López (Eds.), Didáctica de la Estadística, Probabilidad y Combinatoria, 2 (pp. 381-387). Granada, 2015. http://www.estadis.net/3/actas/Actas\%20de\%20las\%202\%20Jornadas\%20Virtuales.pdf

Batanero, C. (2009). Retos para la formación estadística de los profesores. II Encontro de Probabilidade e Estatística na Scola. Universidade do Minho, Braga, Portugal. http://www.ugr.es/ batanero 
Estrada, A. (2007). Actitudes hacia la Estadística: un estudio con profesores de educación primaria en formación y en ejercicio. Actas del XI Simposio de la SEIEM (ISSN: 1888-0762, ISBN: 847985-261-5). 121-140. http://web.udl.es/usuaris/z4084849/es/publicaciones1.html

Jimenez, L., \& Jimenez, J. (2005, mayo). Enseñar probabilidad en primaria y secundaria? ¿Para qué y por qué?. Cidse-Revista virtual matemática- Educación e Internet, v6, n1. http://www.tec-digital.itcr.ac.cr/revistamatematica/contribuciones-v6-n1-may2005/artialeat/index.html

Grima, P. (2010). Estadística: Enseñar y crear actitudes positivas a través de casos prácticos. Revista Iberoamericana de Educación matemática. Número 24 (ISSN: 1815-0640) $11-26$.

Osorio, A. (2012). Análisis de la idoneidad de un proceso de instrucción para la introducción del concepto de probabilidad en la enseñanza superior. Tesis para optar el grado de Magister en Enseñanza de las Matemáticas PUCP http://tesis.pucp.edu.pe/repositorio/handle/123456789/4658

Wild, C., \& Pfannkuch, M. (1999). Statistical Thinking in Empirical Enquiry. International Statistical Review, 67(3), 223-265. 